\title{
THE DRIVERS OF LOCAL COMPETITIVENESS ON THE ROMANIAN MARKET
}

\author{
DIMA, M. A.; LEFTER, V. \& SANDRU, I. M. D.
}

Abstract: The competitiveness could be enhanced only on free markets. Great number of producers and consumers, no political influences in price determination, consumer welfare and consumer satisfaction are common elements to identify markets with free competition. The workable or normal competition should be identified according to the stage of market evolution, specific circumstances and according to the market participants' ranking and perceptions. This paper based on an original research tries to identify the most important factors influencing the contestable market, as they are perceived by the most important players, Romanian companies. The importance of different factors has been tested using regression functions in order to establish statistical correlations between some variables as sales volume or capital nature and the answers provided by the companies.

Key words: contestable market, competitiveness, free competition, business environment, barriers to entry, market research
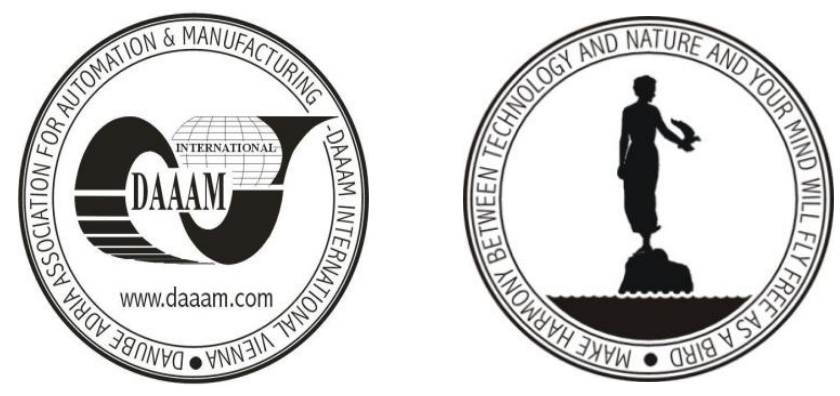

Authors' data: Univ. Assoc. Prof. Dima, M[ihaela] A[lina $]^{*}$; Prof. Lefter, V[iorel]**; Univ. assist. Sandru, I[oana] M[aria] D[iana]*, *Bucharest Academy of Economic Studies, Business Administration Department, Mihail Moxa 5-7, Buchaest, Romania, **Bucharest Academy of Economic Studies, Piata Romana, 1; Buchaest, Romania, alinamihaeladima@yahoo.com, diana_sandru@yahoo.com

This Publication has to be referred as: Dima, M[ihaela] A[lina]; Lefter, V[iorel] \& Sandru, I[oana] M[aria] D[iana] (2010). The Drivers of Local Competitiveness on the Romanian Market, Chapter 54 in DAAAM International Scientific Book 2010, pp. 617-632, B. Katalinic (Ed.), Published by DAAAM International, ISBN 978-3901509-74-2, ISSN 1726-9687, Vienna, Austria

DOI: $10.2507 /$ daaam.scibook.2010.54 


\section{Introduction}

Competitiveness represents a set of capacities and qualities necessary for entering the competition contest. The general assumption is that free market economy is a necessary precondition for the national and international competitiveness.

Free competition or workable competition characteristics identify with the free market economy demands. Market economy mechanism works based on demand and offer, having as central axis the price that ensures the self-regulation of the market balance. To fulfill this role, its setting up must take place in a normal competitive environment.

The normal competitive environment as defined by the present research is determined by the following coordinates:

a. The existence of more producers, and, therefore of more buyers, condition that eliminates the probability of any monopoly, or other forms of dominant position on the market;

b. The existence of the diversification of the types of a considered homogenous product, condition that offers the possibility that potential participants manifest various options on upstream or downstream market, with whom producers and distributors have a market economy relationship;

c. The price decision belongs exclusively to economic agents, thus the government having no interventions in order to set prices at a nominal level;

d. The role of the state in limiting its regulation behavior, in the sense of adopting laws regarding companies' discipline on the market, and supervising their behavior in order to eliminate anti-competitive practices;

e. The tendency to stabilize prices, a phenomenon that proves the existence of the two sides of the market: demand and offer, and their meeting under competition that allows for their balancing through the free price, that in the case is an equilibrium price;

f. The welfare of the final consumers is ensured by the quantitative, qualitative and structural (diversified) existence of the goods on the market, according to the utility recognized by the consumers.

These coordinates that define the normal competitive environment are found in the end in the welfare of the consumer. This actually represents the final objective of free market or contestable market (Mosteanu, 2000).

\section{Literature review}

Very few modern industries conform to the economist's ideal of an open and free market. Most sectors are dominated by a handful of large players, which employ strategies that deliberately marginalize or weaken their competitors. Generally, this is done openly and legally, as firms try to maximize returns for their shareholders. In addition, rivals usually accept the rules of the game, though they may complain if it leads to their key suppliers upping their prices (Bannerman, 2002). Effective, normal, contestable or workable are the most common terms used to define the desirable conditions on the market, although a distinction among these concepts is not clearly 
made. The ideal structure of perfect competition is not met in market reality. Basically, all the concepts refer to an appropriate structure of the market to promote efficiency both for producers and consumers. However, many markets are not contestable and, typically, the behaviour of firms is subject to competition policy legislation to prevent firms form abusing their market position (Accut \& Elliott, 2001).

What "effective competition" means must be formulated clearly; and standards must be set forth which provide guidance and assessment for both "the antitrust laws, which are enforced by a series of cases against designated enterprises, not by general evaluations. It is thus not enough even to formulate certain necessary conditions of workable competition-like no pricing collaboration-although these may be all that the law can impose. The task is to set forth the practically attainable conditions whose presence is both necessary and sufficient in a particular segment if the economy for it to be doing or being what the interest may reasonably demand of it, and whose greater fulfillment would imply greater social benefit. This is the definition of "workable competition" or, to abbreviate, the workability criterion (Sosnick, 1958).

The workability criterion, joined with an emotive label like "optimum competition," will stress the goal of having the best attainable state of affairs in individual markets and emphasize that public service is greater the closer is a market to its optimum. The workable-or-unworkable dichotomy, however, still fails to distinguish different degrees of under-or over fulfillment of the minimum requirements. A preferable alternative is to acknowledge that anything less than ideal is a matter of degree for both individual dimensions and the market situation as a whole, to grant that rating and weighting the several dimensions is subjective, and then to distinguish actual cases by gradations of sub-optimality (Dima \& Vasilache, 2007).

A number of authors propose in effect that competition be considered workable if there are available to traders an adequate number of genuine alternatives. In itself, this criterion merely rephrases the original question. Competition is just the process of providing options or alternatives (Dima, 2007). What is significant for the workability of any one market might be the number, kind, or importance of the price or product options or their providers or receivers. The criterion is not operational until the meaning of "alternatives" and the tests of their adequacy are made concrete. When this is done, it is evident that the notion of adequate alternatives is merely a different label for a workability criterion, which in fact is composed of structure, conduct, or performance norms. Baumol and Willing (1986) review the use of the theory of contestable market in relation to regulation.

Certain structure dimension norms are suggested in the literature: a large or an appreciable number of traders, or several at least, none dominant; as many or at least as many as scale economics permit and price-sensitive quality differential; absence of legal restrictions; firms should strive in rivalry, pursuing their independent judgment and responding without collusion to considerations of profit and loss; firms should not shield permanently inefficient rivals, suppliers, or customers; there should be no unfair, exclusionary, predatory, or coercive tactics; profits should be at levels which reward investment and efficiency and induce innovation; output should be consistent 
with a good allocation of resources; entry should be as free as the nature of the industry permits; excessive political and economic power should not rest in the hands of shall groups; employees' welfare should not be neglected.

From the international literature review, it can be seen that many of the writers are not consistent in their views as to different conditions of the competitive market. Partially, the dominance of one or another market characteristics can be explained by the fact the markets are not uniform. But principally, the explanation for this first fundamental point of difference lies in real differences of ideology, theory, and opinion. Our objective is to now is to determine which dimensions' condition should determine workability. To do so, we must rely on the opinions of the market players.

The market economy was the most important goal of Romania, lately, the essential point for the accession, but there is still a key element for EU in order to accomplish the Lisbon strategy. To determine the characteristics of workable competition on the Romanian market, and thus the level of competitiveness of companies on the Romanian market, we considered necessary to conduct a quantitative survey amongst the companies, a survey that might allow obtaining comprehensive valid and valuable information, to reach relevant conclusions regarding the perception of companies relative to this issue.

\section{Sample size and research methodology}

The analysis of the competitiveness in case of Romanian business sector was based on an exhaustive questionnaire.

\begin{tabular}{|l|c|c|}
\hline Year of establishment & $\begin{array}{c}\text { No of } \\
\text { respondents }\end{array}$ & $\begin{array}{c}\% \text { of } \\
\text { respondents }\end{array}$ \\
\hline Before 1990 & 22 & 5.1 \\
\hline Between 1990 and 1995 & 100 & 23.53 \\
\hline Between 1995 and 2000 & 77 & 18.12 \\
\hline Between 2000 and 2005 & 110 & 25.88 \\
\hline After 2005 & 87 & 20.47 \\
\hline No answer & 29 & 6.82 \\
\hline
\end{tabular}

Tab. 1. Sample structure based on year of company's establishment

This tool was composed by a number of 21 questions ( 7 open questions, 6 multiple choice questions with multiple answers and 8 multiple choice questions with a single answer). In the present paper, we analyze some of these questions. We considered that the following sample criteria are relevant for our study: year of company's establishment (this variable is important for evaluating the market experience of the company); main activity sector of the company; total sales of the company (business dimension); number of employees (business dimension); nature of the company's capital (private or public).

The questionnaires were applied by using operators that directly accessed the managers of the companies. This method ensured a high rate of response and made 
this study significantly relevant for Romanian business sector. The total number of Romanian companies that answered to the questionnaire about competition strategies was 425 .

\begin{tabular}{|l|c|c|}
\hline Activity sector & No of respondents & \% of respondents \\
\hline Services sector & 292 & 68.71 \\
\hline Consumption goods and services & 76 & 17.88 \\
\hline Industrial goods and services & 44 & 10.35 \\
\hline Other sector & 13 & 3.06 \\
\hline Total & 425 & 100 \\
\hline
\end{tabular}

Tab. 2. Sample structure based on activity sector

Taking into consideration the total number of 318.728 companies (2007), the sample size provides an error less than 5\% (assuming a normal distribution formula). The majority of the respondents are companies set up after 1990 during the transition period (more than 66\% of companies were set up between 1990 and 2005).

A very important number of companies $(20.5 \%)$ are new established companies with a reduced market experience. The major part of the companies have as a major field of activity the service field, provided to the market (around 69\% from total answers).

On the second place, the respondents are companies that act in the field of providing goods and services for industry (around 10\%). Few answers indicated of consumption goods and services (around 18\%) and companies in the field other sectors such as: security sector or, juridical sector (most of them could be included also in the services sector or sector of goods and services for consumers).

\begin{tabular}{|l|c|c|}
\hline Total sales (million euro) & No of respondents & \% of respondents \\
\hline Below 3.99 & 270 & 63.5 \\
\hline Between 4 and 7.99 & 49 & 11.5 \\
\hline Between 8-12 & 18 & 4.2 \\
\hline Over 12 & 77 & 18.1 \\
\hline No answer & 11 & 2.6 \\
\hline Total & 425 & 100 \\
\hline
\end{tabular}

Tab. 3. Sample structure based on sales level

The major part of the companies (around 90\%) that answered to the proposed questionnaire is concentrated on companies with sales that are less than $12 \mathrm{~m}$ Euros and that could be included in the category of Small and Medium Enterprises (SME) (see table 3). The companies with less than nine employees are dominant in our sample (36\%). On the second place, we have companies with less than 49 employees (29.41\%). However, the SMEs are dominant in our sample (around 90\% of companies) and we consider that this structure is relevant for Romanian market (there is a similar situation in European Union too, where more than $90 \%$ of the total companies are SMEs). 
Dima, M.A.; Lefter, V. \& Sandru, I.M.D.: The Drivers of Local Competitiveness ...

\begin{tabular}{|l|c|c|}
\hline Number of employees & No of respondents & $\%$ of respondents \\
\hline 2-9 employees & 153 & 36 \\
\hline 10-49 employees & 125 & 29.41 \\
\hline $50-249$ employees & 67 & 15.76 \\
\hline 250-999 employees & 41 & 9.65 \\
\hline over 1000 employees & 39 & 9.18 \\
\hline Total & 425 & 100 \\
\hline
\end{tabular}

Tab. 4. Sample structure based on number of employees

The major part of companies that answered to the study have private capital, mostly being Romanian companies (more than 59\% of companies declared to have only Romanian private capital, while $8 \%$ of companies majority Romanian private capital). A very interesting situation that makes relevant our study is due to the fact that an important number of companies have foreign investors as shareholders.

\begin{tabular}{|l|c|c|}
\hline Nature of capital & $\begin{array}{c}\text { No of } \\
\text { respondents }\end{array}$ & $\begin{array}{c}\% \text { of } \\
\text { respondents }\end{array}$ \\
\hline 100\% public capital & 16 & 3.76 \\
\hline public capital in majority & 3 & 0.71 \\
\hline Private capital, 100\% Romanian capital & 253 & 59.53 \\
\hline Private capital, Romanian capital in majority & 34 & 8 \\
\hline Private capital, foreign capital in majority & 63 & 14.82 \\
\hline Private capital, 100\% foreign capital & 52 & 12.24 \\
\hline No answer & 4 & 0.94 \\
\hline TOTAL & 425 & 100 \\
\hline
\end{tabular}

Tab. 5. Sample structure based on nature of the capital

On a marginal position are placed companies publicly owned (or mainly). We consider that this structure is relevant for Romanian business sector that is highly dominated by private companies. Only in case of private business, we discuss about competition strategies. The approach of this particular field could be also different in case of local companies than foreign ones.

\section{Data analysis and interpretation}

\subsection{The nature of the barriers on the company's market}

It has been suggested that greater contestability of industries should be encouraged, for example through policies aimed at reducing entry barriers (WeimanJones, 1994). In our study, $13 \%$ of the respondents consider that governmental intervention is an important barrier/threat on their market, while 39.72 that legal barriers. Klevorick (1973), Bawa \& Sibley (1980), Logan et al. (1980) and Glazer \& McMillan (1992), confirms that the threat of regulation can impinge upon a firm's behavior. Glazer \& McMillan (1992) developed a model of monopoly price regulation, whilst the earlier papers focus on industry specific regulation of 
monopolistic firms to achieve a 'fair rate-of-return' (Simkin and Cheng, 1997). A limited number of empirical studies have also been published that explore the threat of regulation on firms' behaviour. The threat of intervention in the theory of contestable markets is considered affecting the production and prices decisions made by incumbent firms in an industry.

The largest number of respondents (60.28\%) considers that the competitors' behavior is the most important barrier for their activity on the market, while $19.39 \%$ consider that production capacity of their competitors is a threat.

\begin{tabular}{|l|c|c|}
\hline Answer & $\begin{array}{c}\text { No of } \\
\text { respondents }\end{array}$ & $\begin{array}{c}\% \text { of } \\
\text { respondents }\end{array}$ \\
\hline Governmental interventions & 55 & $13.00 \%$ \\
\hline Legal barriers & 168 & $39.72 \%$ \\
\hline The competitors' behaviour & 255 & $60.28 \%$ \\
\hline Production capacity of the competitors & 82 & $19.39 \%$ \\
\hline Technological barriers & 76 & $17.97 \%$ \\
\hline No barriers & 43 & $10.17 \%$ \\
\hline Others & 36 & $8.51 \%$ \\
\hline
\end{tabular}

Tab. 6. The opinion of the respondents related to the types of the barriers on their market

\section{Types of barriers on the market}

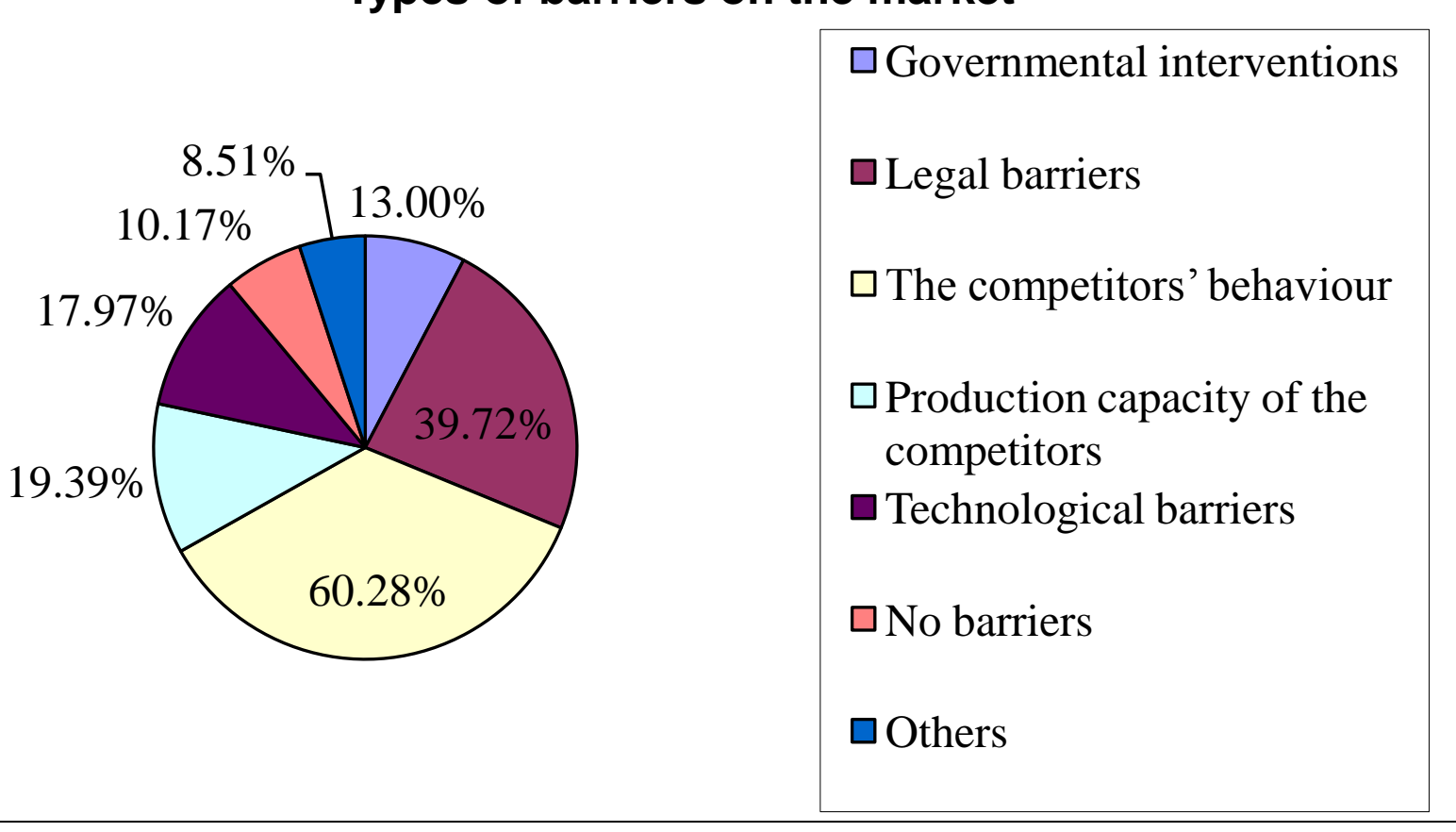

Fig. 1. The opinion of the respondents related to the types of the barriers on their market

Aaker (1995) considers that while the identification of competitors is crucial, it is often more complex than generally acknowledged. Key competitors will be those, which battle most fiercely and prominently with the basic business of the company. Having identified the competitors, the next step is to know what to do: to try to 
Dima, M.A.; Lefter, V. \& Sandru, I.M.D.: The Drivers of Local Competitiveness ...

understand their ability in different aspects and their strategy. $17.97 \%$ respondents identify technological barriers on their market.

\subsection{Information related to the way of setting up the price on the market}

The ideal situation on a competitive market is that prices should be freely established as a result of correlation between demand and supply of a certain product on the market and not regulated by the state. $40.47 \%$ respondents mentioned that the price on their market is free, while only $2.35 \%$ declared that is fixed by the state. As Acutt \& Elliott (2001) mentioned, the optimal price to be charged depends on the market structure. For example, in a contestable oligopoly, price will be equal to marginal cost.

\begin{tabular}{|l|c|c|}
\hline Answer & $\begin{array}{c}\text { No of } \\
\text { respondents }\end{array}$ & $\begin{array}{c}\text { \% of } \\
\text { respondents }\end{array}$ \\
\hline $\begin{array}{l}\text { The price is free, as a result of demand and supply } \\
\text { on the market }\end{array}$ & 195 & 45.88 \\
\hline $\begin{array}{l}\text { The price is influenced by the main competitors on } \\
\text { the market }\end{array}$ & 172 & 40.47 \\
\hline The price is regulated by the state & 10 & 2.35 \\
\hline The price is fixed at the level of branch association & 15 & 3.53 \\
\hline $\begin{array}{l}\text { The price is influenced by one of the main } \\
\text { competitors, as informal leader on the market }\end{array}$ & 10 & 2.35 \\
\hline Others & 21 & 4.94 \\
\hline
\end{tabular}

Tab. 7. The opinion of the respondents related to the price of product/service

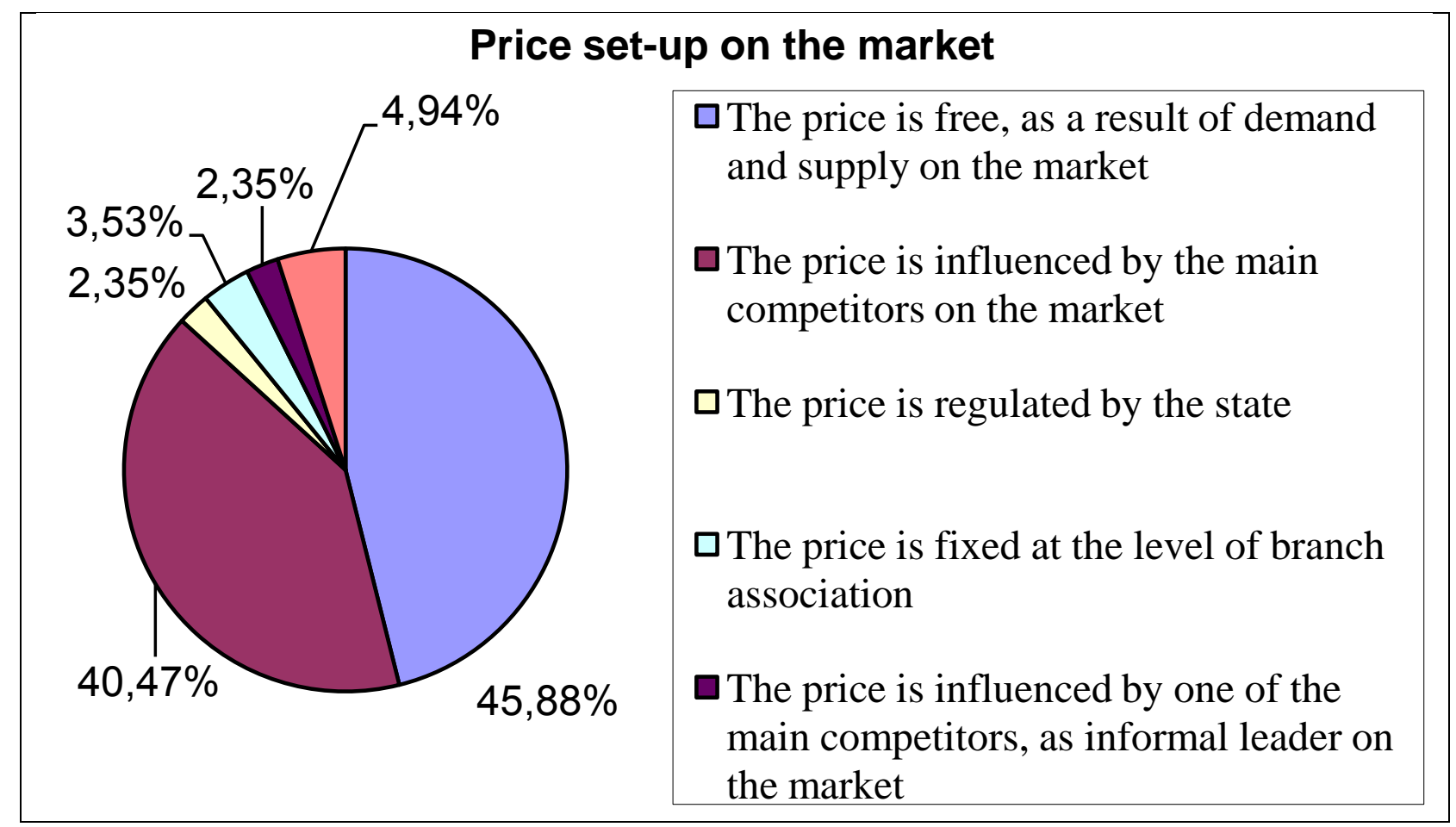

Fig. 2. The opinion of the respondents related to the price set-up of a product/service

However, many markets are not contestable and typically the behavior of the firms is subject to competition policy legislation to prevent firms from abusing their 
market position or agree with other competitors (usually at the level of association) to fix the price on the market of a certain product. Often, on oligopolistic market, the others will follow the price of the informal leader. Thus, $40.47 \%$ respondents answered that the main competitors on the market influence the price, $3.53 \%$ that is fixed at the level of association and $2.35 \%$ that is influenced by one competitor, the informal leader on the market (see table 7).

\subsection{The main objective of the company}

The main objective of the competition policy is the final consumer satisfaction and not the protection of the consumers on the market. Thus, the companies should pursue this objective when setting up their business strategy. $47.29 \%$ of the respondent companies stated that their main objective is the final consumer satisfaction. Maximization of the company's profit $(21.18 \%)$, increasing the market quota $(24.71 \%)$, acquiring new market segments $(4.00 \%)$ are different objectives of the respondent companies that might contradict the competition policy goals and lead to the infringement of legislation in this field.

\begin{tabular}{|l|c|c|}
\hline Answer & No of respondents & \% of respondents \\
\hline The final consumer satisfaction & 201 & 47.29 \\
\hline Maximization of company's profit & 90 & 21.18 \\
\hline Increasing the market quota & 105 & 24.71 \\
\hline Acquiring new market segments & 17 & 4.00 \\
\hline Elimination of main competitors & 4 & 0.94 \\
\hline Others & 6 & 1.41 \\
\hline
\end{tabular}

Tab. 8. The opinion of the respondents related to the main objective of the company

\section{The main objective of a company}

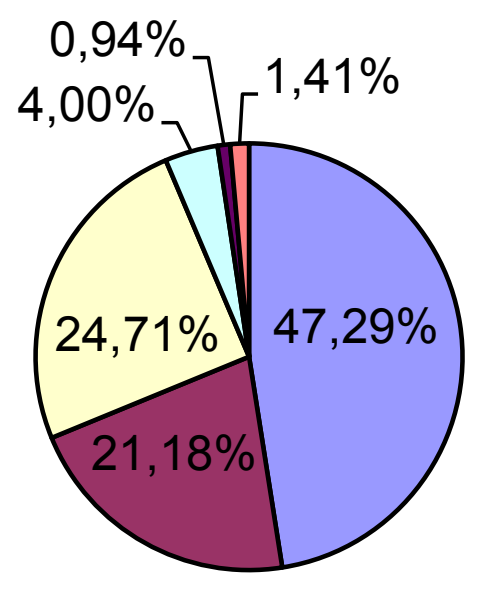

$\square$ The final consumer satisfaction

Maximization of company's profit

$\square$ Increasing the market quota

$\square$ Acquiring new market segments

Elimination of main competitors

口Others

Fig. 3. The opinion of the respondents related to a company's main objective 
Dima, M.A.; Lefter, V. \& Sandru, I.M.D.: The Drivers of Local Competitiveness ...

4.4 Identification of competitors in the market

Aaker (1995) believes that while the identification of competitors is crucial, it is often more complex than generally acknowledged. He suggested seven central to understanding competition.

These factors provide guidelines for companies analyzing competitors (Simkin \& Cheng, 1997):

- Level and growth rates, sales and market share indicators provide an indication of the vitality of a business strategy.

- Knowing a competitor's objective and its assumptions may help to predict that company's moves. The objective could be defined in terms of financial performance, technological advancement or marketing concerns of market share, brand perception and customer satisfaction.

- Competitors' current and past strategies should be reviewed: businesses are often surprisingly predictable and, if a tactic worked in the past, it is likely to be repeated (Simkin, 1996b).

- Knowledge of the background and experience of a rival's top management may provide an insight into that company's future direction.

- All businesses are concerned with their cost structures and available resources. Attempting to estimate competitors' positions may give important clues as to their viable future intentions.

- Exit barriers may be high, forcing a struggling business to remain active in a market. An understanding of rivals' exit barriers may indicate how doggedly they will fight on in a market.

- Assessing the strengths and weaknesses of rivals is essential if a business is to develop its strategy to compete effectively and on the best possible basis.

The majority of the respondents to the questionnaire claim to monitor their competitive situation: $62.12 \%$ respondents (264) consider that on the market they are operating, there are more than 20 companies, meaning that the market could be considered a very competitive one (or contestable).

\begin{tabular}{|l|c|c|}
\hline Answer & No of respondents & \% of respondents \\
\hline Only one company (yours) & 5 & 1.18 \\
\hline 2-5 companies & 44 & 10.35 \\
\hline 6-20 companies & 111 & 26.12 \\
\hline More than 20 companies & 264 & 62.12 \\
\hline
\end{tabular}

Tab. 9. The respondents' opinion related to the number of competitors

$26.12 \%$ of the companies play on a market with maximum 20 competitors, while $10.35 \%$ have maximum five competitors. Only five companies out of the respondents suggest that their competitive market does not exist, being the only one player on the market. 


\section{Competitors on the market}

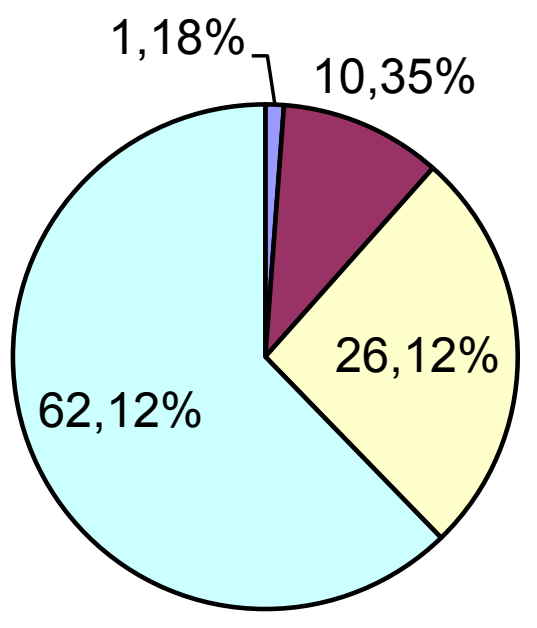

口Only one company (yours)

口2-5 companies

口6-20 companies

पMore than 20 companies

Fig. 4. The respondents' opinion related to the number of companies on the market

The fact that competition in and for a market are not prefect substitutes carries a strong implication, namely that the fact that many firms compete in a market does not mean that there are many competitors for that market.

\begin{tabular}{|l|c|c|}
\hline Answer & No of respondents & \% of respondents \\
\hline Very strong & 218 & 51.29 \\
\hline Rather strong & 132 & 31.06 \\
\hline Neither weak, or strong & 64 & 15.06 \\
\hline Rather weak & 6 & 1.41 \\
\hline Very weak & 5 & 1.18 \\
\hline
\end{tabular}

Tab. 10. The opinion of the respondents related to the level of competition

\section{The level of competition on the market}

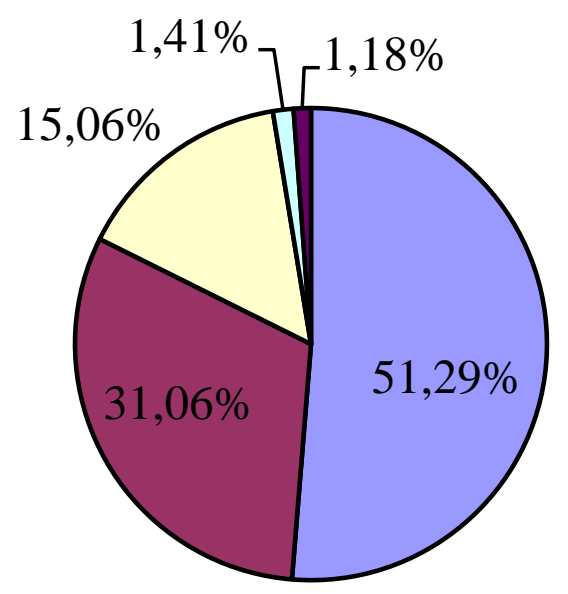

Very strong

$\square$ Rather strong

$\square$ Neither weak, or strong

$\square$ Rather weak

$\square$ Very weak

Fig. 5. The opinion of the respondents related to the level of competition 
However, the answers to the following question are consistent with the previous question, since the most of the companies included in the sample $(82.35 \%)$ consider the competition on their market very strong or rather strong.

As compared to this a very low percentage $(2.59 \%)$ consider the competition rather weak or very weak. $15.06 \%$ of the respondent companies suggest that the competition is neither weak or strong on their market.

Vigorous competition in a market typically forces firms to focus on efficiency enhancement, getting costs out and on process innovation. Innovative entrants try to encourage consumers and complementary producers to do something different, to invest in a new product and in a new pattern of consumption or production behavior.

\section{Analysis of relevant statistical correlations}

One of the paper's objectives is to determine relevant factors influencing the level of contestability on the Romanian market and thus the level of competitiveness of the Romanian business environment. The significance of different factors, such as a company's activity sector, the sales volume, a company's number of employees, and the nature of capital (form of property) have been tested by taking into account the answers provided to the questionnaire.

In order to test the significance of these factors, regression functions between the above mentioned factors and the answers provided to the questions mentioned in tables no. 6-10 have been used. In case of each of the five questions, namely types of barriers on the market, level of competition, number of competitors, a company's main objective, price of a product/service, the answers given by most of the respondents have been analyzed within the regression built.

To test the relevance of the above mentioned four factors in connection with the five different aspects, the answers provided to the questions have been used as dependent variables. Each ticked answer choice (no matter if referring to the four independent factors or to the five dependent aspects) has been marked by 1 , and the ones left unticked by 0 .

The analysis shows that between a company's activity sector and the number of competitors on the market there is a positive correlation (see tab. 11). In this case the dependent variable, namely "the number of companies on the market is higher than 20 firms" is given by $62.12 \%$ of the subjects in the survey (see tab. 9). Though weak (multiple $r=0.158$ ), this correlation is stronger as compared with the values obtained for the other four variables. Since significance F is 0.029 (less than 0.05), the correlation between the two variables is statistically significant, but because of high p-values the correlation is statistically insignificant over the sample space of the survey.

The results are not statistically relevant in case of the relationship between a company's activity sector and the types of barriers on the market, respectively the price of a product/service, a company's main objective, and the competition level in the respective field (positive, but not statistically significant correlations due to pvalues and Significance F levels higher than 0.05). 
The analysis provides no statistically significant results (both p-values and Significance F levels are higher than 0.05) in case of the correlations between "a company's sales volume" and each of the five variables.

The same situation occurs in case of the correlation between "a company's number of employees" and the types of barriers on the market, respectively the price of a product/service, a company's main objective, and the competition level. The correlation regarding the number of companies on the market displays a positive "multiple R" which equals 0.21 , and a significance $F$ equal with 0.029 , but is statistically insignificant over the sample area of the survey with p-values higher than 0.05 .

\begin{tabular}{|l|r|}
\hline \multicolumn{2}{|c|}{ Regression Statistics } \\
\hline Multiple R & 0.158 \\
\hline R Square & 0.025 \\
\hline Adjusted R Square & 0.015 \\
\hline Standard Error & 0.481 \\
\hline Observations & 425 \\
\hline
\end{tabular}

\begin{tabular}{|c|c|c|c|c|c|c|c|c|}
\hline & Coefficients & \begin{tabular}{|c|} 
Standard \\
Error \\
\end{tabular} & $t$ Stat & $P$-value & $\begin{array}{c}\text { Lower } \\
95 \%\end{array}$ & \begin{tabular}{|l|} 
Upper \\
$95 \%$
\end{tabular} & \begin{tabular}{|l|} 
Lower \\
$95,0 \%$ \\
\end{tabular} & $\begin{array}{l}\text { Upper } \\
95,0 \%\end{array}$ \\
\hline Intercept & 0.557 & 0.132 & 4.207 & $3.15 \mathrm{E}-05$ & 0.297 & 0.818 & 0.297 & 0.818 \\
\hline Services sector & 0.067 & 0.130 & 0.518 & 0.604 & -0.189 & 0.325 & -0.189 & 0.325 \\
\hline $\begin{array}{l}\text { Consumption } \\
\text { goods and } \\
\text { services }\end{array}$ & 0.096 & 0.133 & 0.725 & 0.468 & -0.165 & 0.358 & -0.165 & 0.358 \\
\hline \begin{tabular}{|l} 
Industrial \\
goods and \\
services
\end{tabular} & -0.162 & 0.147 & -1.098 & 0.272 & -0.453 & 0.128 & -0.453 & 0.128 \\
\hline Other sector & 0.128 & 0.134 & 0.954 & 0.340 & -0.135 & 0.391 & -0.135 & 0.391 \\
\hline
\end{tabular}

Tab. 11. Correlation between the number of competitors and a company's activity sector

Referring to the correlation between the factor "form of property" (by this referring to "the nature of capital") and each of the five questions, relevant results are registered in case of two correlations:

- There is a positive relationship between the form of property and the number of competitors on the market (multiple $\mathrm{R}=0.241$ ) which is generally statistical significant (Significance $\mathrm{F}=0.0003$ ), but insignificant over the sample area of the survey (p-values are higher than 0.05);

- The relationship between the form of property and the level of competition in a certain field of activity is presented in tab. 12. The aspect considered within the regression refers to $51.29 \%$ of the respondents for whom competition is very strong on the market. The correlation is both positive (multiple $\mathrm{R}=0.196$ ) and statistically significant (Significance F $=0.010$ ).

The analysis shows that within a field of activity under very strong competition, 
Dima, M.A.; Lefter, V. \& Sandru, I.M.D.: The Drivers of Local Competitiveness ...

companies with:

- private, $100 \%$ Romanian capital (p-value $=0.04$ ),

- private, mostly foreign capital ( $\mathrm{p}$-value $=0.018$ ), and

- private, $100 \%$ foreign capital $(p-$ value $=0.011)$

have a very high influence on the competition nature in a field of activity.

\begin{tabular}{|lr|}
\hline \multicolumn{2}{|c|}{ Regression Statistics } \\
\hline Multiple R & 0.196 \\
\hline R Square & 0.038 \\
\hline Adjusted R Square & 0.024 \\
\hline Standard Error & 0.494 \\
\hline Observations & 425 \\
\hline
\end{tabular}

\begin{tabular}{|c|c|c|c|c|c|c|c|c|}
\hline & Coeff. & $\begin{array}{c}\text { Standard } \\
\text { Error }\end{array}$ & t Stat & P-value & $\begin{array}{c}\text { Lower } \\
95 \%\end{array}$ & $\begin{array}{c}\text { Upper } \\
95 \%\end{array}$ & $\begin{array}{l}\text { Lower } \\
95,0 \%\end{array}$ & $\begin{array}{l}\text { Upper } \\
95,0 \%\end{array}$ \\
\hline Intercept & $2.01 \mathrm{E}-16$ & 0.247 & $8.12 \mathrm{E}-16$ & 0.999 & -0.485 & 0.485 & -0.485 & 0.485 \\
\hline $\begin{array}{l}100 \% \text { public } \\
\text { capital }\end{array}$ & 0.437 & 0.276 & 1.583 & 0.113 & -0.105 & 0.980 & -0.105 & 0.980 \\
\hline $\begin{array}{l}\text { Public capital } \\
\text { in majority }\end{array}$ & $-2.1 \mathrm{E}-16$ & 0.377 & $-5.7 \mathrm{E}-16$ & 0.999 & -0.741 & 0.741 & -0.741 & 0.741 \\
\hline $\begin{array}{l}\text { Private capital, } \\
100 \% \\
\text { Romanian } \\
\text { capital }\end{array}$ & 0.498 & 0.249 & 1.9995 & 0.046 & 0.008 & 0.987 & 0.008 & 0.987 \\
\hline $\begin{array}{l}\text { Private capital, } \\
\text { Romanian } \\
\text { capital in } \\
\text { majority } \\
\end{array}$ & 0.382 & 0.261 & 1.463 & 0.143 & -0.131 & 0.895 & -0.131 & 0.895 \\
\hline $\begin{array}{l}\text { Private capital, } \\
\text { foreign capital } \\
\text { in majority }\end{array}$ & 0.603 & 0.254 & 2.367 & 0.018 & 0.102 & 1.104 & 0.102 & 1.104 \\
\hline $\begin{array}{l}\text { Private capital, } \\
100 \% \text { foreign } \\
\text { capital }\end{array}$ & 0.653 & 0.256 & 2.550 & 0.011 & 0.149 & 1.157 & 0.149 & 1.157 \\
\hline
\end{tabular}

Tab. 12. Correlation between the level of competition and a company's capital nature

It can be stated thus, that the form of property is one of the drivers that greatly influences the level of competition on the market, and thus the level of competitiveness of the Romanian companies.

The correlations of the other variables, namely types of barriers on the market, price of a product/ service and a company's main objective, with the "form of property" are statistically insignificant, higher "p-values" and levels of Significance F being obtained. 
Finally, we can conclude that, from a statistical point of view there is a positive correlation and generally significant correlation between: the number of companies (competitors) on the market with each of the following factors: a company's activity sector, a company's number of employees and a company's nature of capital. These factors are generally considered important drivers for the competitiveness level on the Romanian market, but relevant results over the sample area of the survey are obtained between the form of property of a company and the nature of competition within a field of activity.

According to the data, the sales' volume, the price of the product/service, and the competition level are not important drivers that could influence in a significant way the competitiveness of the companies on the Romanian market.

\section{Conclusions}

The statistical analysis shows that there exists a correlation between some of the variables. The number of companies on the market (the structure of competition on the market) varies with the company's main field of activity. At the same time, the number of companies on the market (the level of competition) is influenced by a company's number of employees. On the other hand, variations in the nature of capital are reflected through the following variables: the number of companies on the market and the level of competition within a field of activity. The conclusions that can be drawn from the analysis suggest that both the specificity of the market and the nature and impact of various factors have to be taken into account when evaluating the market contestability. Only on contestable (highly competitive) markets it could be assessed the level of competitiveness of the most important players, the companies. Future research focuses on more specific analysis based on sectors of activity.

\section{References}

Aaker, D. (1995). Strategic Marketing Management, John Wiley, New York, NY. Accut, M. and Elliot, C. (2001). Threat-Based competition policy, European Journal of Law and Economics, 11:3; 309-317, Kluwer academic publishers, Netherlands, indexed in Social Science Citation Index, ISSN 0929-1261

Ball, D.A. \& McCulloch, W.H. (1996). International Business. The challenge of global competition, sixth edition, the McGraw-Hill Companies, Inc Bannerman, E. (2002). The future of EU competition policy, Centre for European Reform, Available from: http://www.cer.org.uk/pdf/cerwp_13fcp.pdf Accessed: 2009-06-29

Baumol, W.J. and Willing, R.D. (1986). Contestability: Developments Since the Book, Oxford Economic Papers, Supplement, no. 38, pp. 9-36. Online ISSN 1464-3812 - Print ISSN 0030-7653

Bawa, V. S. \& Sibley, D. S. (1980). Dynamic Behaviour of a Firm Subject to Stochastic Regulatory Review, International Economic Review, 21, 627-642, Print ISSN: 0020-6598, Online ISSN: 1468-2354 
Dima, M.A.; Lefter, V. \& Sandru, I.M.D.: The Drivers of Local Competitiveness ...

Dima, A. \& Vasilache, S. (2007). The competition policy at the crossroads: the new challenges on the enlargement process in European Union at the crossroads: the need for constitutional and economic changes, Justyna MaliszerwskaNienartowicz (Ed.), Jean Monnet Centre for European Studies Nicolaus Copernicus University in Torun, Poland, pp 161-172, ISBN 978-83-7285-3431

Dima, A. (2007). Competition challenges for Romanian business environment. Management\&Marketing Journal, Economica publishing house, no 1, ISSN 1842-0206, pp. 87-102

Glazer, A. \& McMillan, H. (1992). Pricing by the Firm under Regulatory Threat. Quarterly Journal of Economics, no. 107, pp. 1089-1099, ISSN 0033-5533 E-ISSN 1531-4650

Klevorick, A. K. (1973). The Behaviour of a Firm Subject to Stochastic Regulatory Review, Bell Journal of Economics and Management Science, no. 4, pp. 57-83, ISSN 00058556

Logan, J. W., Masson, R. T. \& Reynolds, R. J. (1989). Efficient Regulation with Little Information: Reality in the Limi?, International Economic Review. 30, 851-861 Print ISSN: 0020-6598, Online ISSN: 1468-2354

Mosteanu, T. (2000). Competition and prices, Economica publishing house, Bucharest, ISBN: 973-30-9493-5

Simkin, L. \& Cheng, A. (1997). Understanding competitors' strategies: the practitioner-academic gap, Marketing Intelligence and Planning, 15/3, pp. 124134, MCB University Press, ISSN: 0263-4503

Simkin, L. (1996). Addressing organisational prerequisites in marketing planning programmes, Marketing Intelligence and Planning, Vol. 14 No. 5, pp. 39-46 ISSN: 0263-4503

Sosnick, S. (1958). A critique of concepts of workable competition, The quarterly Journal of Economics, Vol. 72, No. 3, pp. 380-423, Harvard University, ISSN $0033-5533$

Stuyck, J. (2005). EC Competition Law After Modernisation: More Than Ever in the Interest of Consumers, Journal of Consumer Policy, vol.28, pp.1-30, ISSN 0168-7034 (Print) 1573-0700 (Online)

Weiman-Jones, T. (1994). Deregulation in D.M Jackson and C.M. Price (eds.), Privatisation and Regulation: A review of the Issues, London, Logman 